\title{
Reasonable People Did Disagree: Optimism and Pessimism About the U.S. Housing Market Before the Crash
}

\author{
Kristopher S. Gerardi, Christopher L. Foote, and Paul S. Willen
}

\begin{abstract}
:
Understanding the evolution of real-time beliefs about house price appreciation is central to understanding the U.S. housing crisis. At the peak of the recent housing cycle, both borrowers and lenders appealed to optimistic house price forecasts to justify undertaking increasingly risky loans. Many observers have argued that these rosy forecasts ignored basic theoretical and empirical evidence that pointed to a massive overvaluation of housing and thus to an inevitable and severe price decline. We revisit the boom years and show that the economics profession provided little such countervailing evidence at the time. Many economists, skeptical that a bubble existed, attempted to justify the historic run-up in housing prices based on housing fundamentals. Other economists were more uncertain, pointing to some evidence of bubble-like behavior in certain regional housing markets. Even these more skeptical economists, however, refused to take a conclusive position on whether a bubble existed. The small number of economists who argued forcefully for a bubble often did so years before the housing market peak, and thus lost a fair amount of credibility, or they make arguments fundamentally at odds with the data even ex post. For example, some economists suggested that cities where new construction was limited by zoning regulations or geography were particularly "bubble-prone," yet the data shows that the cities with the biggest gyrations in house prices were often those at the epicenter of the new construction boom. We conclude by arguing that economic theory provides little guidance as to what should be the "correct" level of asset prices -including housing prices. Thus, while optimistic forecasts held by many market participants in 2005 turned out to be inaccurate, they were not ex ante unreasonable.
\end{abstract}

\section{JEL Classifications: G12, G14, G21, B23}

Kristopher S. Gerardi is a research economist and assistant policy advisor in the research department at the Federal Reserve Bank of Atlanta. His e-mail address is kristopher.gerardi@atl.frb.org. Christopher L. Foote is a senior economist and policy advisor at the Federal Reserve Bank of Boston. His e-mail address is chris.foote@bos.frb.org. Paul S. Willen is a senior economist and policy advisor at the Federal Reserve Bank of Boston. His e-mail address is paul.willen@bos.frb.org.

This paper, which may be revised, is available on the web site of the Federal Reserve Bank of Boston at http://www.bos.frb.org/economic/wp/index.htm. Originally prepared for the conference, “The American Mortgage System: Rethink, Recover, Rebuild," held in Philadelphia, PA on May 12-14, 2010, it will appear in the forthcoming book, Reinventing the American Mortgage System: Rethink, Recover, Rebuild, coedited by Marvin Smith and Susan M. Wachter, that will be published in Spring 2011. We thank Susan Wachter, Jeff Fuhrer, Elizabeth Murry, and two anonymous reviewers for helpful comments.

The views expressed in this paper are those of the authors and do not necessarily represent those of the Federal Reserve Bank of Atlanta, the Federal Reserve Bank of Boston, or the Federal Reserve System.

This version: September 10, 2010 


\section{Introduction}

The home-price bubble feels like the stock-market mania in the fall of 1999, just before the stock bubble burst in early 2000, with all the hype, herd investing and absolute confidence in the inevitability of continuing price appreciation.

Robert Shiller Quoted in "The Bubble's New Home" by Jonathan R. Laing, Barron's (2005)

Optimism about future house price growth shoulders much of the blame for the mortgage crisis that swamped the U.S. and world economies starting in 2007. Had borrowers and investors in 2006 known that the nearly decade-long expansion of the U.S. housing sector had ended and that house prices would decline 30 percent over the next three years, few would have made the decisions they did.

But to many, the fact that investors and borrowers were optimistic about house prices in 2006 seems inexplicable or even inexcusable. The experience up to that point showed all the hallmarks of an asset-pricing bubble. From 1997:Q1 to 2005:Q1, real home prices went up 72 percent according to the Case-Shiller repeat-sales index, and by 41 percent according to the OFHEO (now FHFA) repeat-sales index. To put these numbers in perspective, according to Shiller (2006), real house prices in the United States were basically flat between the late 1940s and the mid-1990s. ${ }^{1}$ Even more striking is the fact that average real house prices in the mid-1990s were at essentially the same level as they were in the late $1890 \mathrm{~s}^{2}$ The divergence of house price appreciation from long-run trends appears not only when one looks at the level of house prices but also if one considers the ratio of house prices to income or rents.

The view that optimism was unjustified in 2005 is not just hindsight. Some observers argued at the time that housing was overvalued and likely to crash. Among the pessimists were economists, like Robert Shiller, quoted above. Some journalists, most notably at The Economist, also argued for the inevitable collapse of the U.S. residential real estate market. ${ }^{3}$

\footnotetext{
${ }^{1}$ OFHEO is an acronym for the Office of Federal Housing Enterprise Oversight, which regulated the large government-sponsored housing enterprises (Fannie Mae and Freddie Mac) before they were placed into conservatorship in September 2008. OFHEO's regulatory role has been taken over by the Federal Housing Financing Agency (FHFA), which has also continued to produce OFHEO's repeat-sales house price index.

${ }^{2}$ According to Shiller (2006), there was a large decline in real prices after World War I that was completely offset by a large increase in prices from 1942 to 1947.

${ }^{3}$ In addition, John Cassidy, a journalist at The New Yorker, wrote "The Next Crash," a prescient discussion of housing-market valuations relatively early in the boom (Cassidy 2002). Many blogs also followed housing-market developments in real time. "Calculated Risk" was one of the notable blogs that took a pessimistic view of the market.
} 
The main question that motivates this paper is why market participants were so optimisticin other words, why they largely ignored the pessimists. Our answer is somewhat surprising: the pessimistic case was a distinctly minority view, especially among professional economists. We review the academic literature written during the housing boom, focusing closely on the period 2004-2006, which turned out to be the peak of the boom. This review indicates that there were widely dispersed opinions on whether the market accurately valued housing. As noted above, some economists were truly pessimistic and warned of an impending collapse in real estate markets with severe consequences. But other economists were truly optimistic and dismissed such warnings. Granted, some of these optimists were real estate industry boosters such as David Lereah, an economist with the National Association of Realtors, who in 2006 published Why the Real Estate Boom Will Not Bust-And How You Can Profit from It. But many in the optimistic camp were serious researchers with established reputations who made convincing arguments in respected academic forums. These optimists cannot be dismissed as purveyors of self-serving industry propaganda, nor as scholars who would dismiss counterarguments without giving such opposing viewpoints due consideration.

The most prevalent opinion among economists who studied house pricing during the bubble was essentially no judgment at all —we call it an "agnostic" view. Agnostics were unwilling to make anything more than guarded, highly qualified statements on the future path of U.S. housing prices. The discussion by Gallin (2008) is typical of this genre:

Because a low rent-price ratio has been a harbinger of sluggish price growth since 1970, it seems reasonable to treat the rent-price ratio as a measure of valuation in the housing market. Indeed, one might be tempted to cite the currently low level of the rent-price ratio as a sign that we are in a house price "bubble." However, several important caveats argue against such a strong conclusion and in favor of future research. (p. 19)

In a sense, this reluctance to commit should not surprise anyone familiar with modern assetpricing theory. The "Fundamental Theorem of Asset Pricing" implies that the evolution of asset prices is, to a first approximation, unpredictable. If housing was so obviously overvalued, as the pessimists suggested, then investors stood to make huge profits by betting against housing. By doing so, investors would have ensured that house prices would have fallen immediately. Regardless of whether the theory of the unpredictability of asset prices is correct, the theory is part of the basic training of almost every economist. Consequently, any economist who suggests to his or her peers that an asset is over- or under-valued faces a heavy burden of proof. ${ }^{4}$ This hurdle may explain why the arguments of some of the

\footnotetext{
${ }^{4}$ We argue that the fundamental theory of asset pricing is one reason why the agnostic economists were reluctant to predict falling housing prices, but it may not have been the only reason. Economists at policy institutions may have shied away from making pessimistic predictions for fear of spooking the markets. And
} 
pessimists early in the boom were largely dismissed at the time.

It is instructive to read the logic of non-economists who looked at house price data in the same period. Paolo Pellegrini and John Paulson, whose wildly successful 2006 bet against subprime mortgages is now the stuff of Wall Street legend, made the following argument, as chronicled in Zuckerman (2009). First, they noted that house prices had deviated from trend:

Suddenly, the answer was as plain as the paper in front of him: Housing prices had climbed a puny 1.4 percent annually between 1975 and 2000, after inflation was taken into consideration. But they had soared over 7 percent in the following five years, until 2005. The upshot: U.S. home prices would have to drop by almost 40 percent to return to their historic trend line. (p. 107)

Those facts are indisputable, but the logic that followed would have earned the two investors a zero on an undergraduate finance exam:

To Paulson and Pellegrini, their discovery meant that housing prices were bound to fall, at least at some point, no matter what the moves in unemployment, interest rates, or the economy. (p. 108)

The "fundamental theorem of asset prices," in its pure form, largely rejects the idea that prices mean-revert, which is what Paulson and Pellegrini assumed. Researchers have found evidence of mean reversion, but Lo and MacKinlay (2001) argue that it operates on a relatively small scale, and that research has not "uncovered tremendous untapped profit opportunities" (p. xxii). In other words, academic finance provided little support for mean reversion on the scale that Paulson and Pellegrini expected.

Economists who argued that house prices were going to fall made two closely related arguments. The first was that key relationships in the data had deviated from long-run averages. The second was that there was a bubble in house prices, so that buyers were willing to pay high prices today because of their expectations of even higher prices tomorrow. Proving either claim was a challenge.

Regarding the first argument, the key data relationships most often analyzed were the ratios of house prices to either incomes or rents. Making a convincing argument that these relationships had deviated from long-run or equilibrium values was far harder than it sounds. Simply measuring these ratios, for example, was an enormous challenge, because different repeat-sales indices of house prices often yielded different results. Moreover, results based on repeat-sales measures of prices differed sharply from results generated by hedonic pricing models. An additional practical complication with using the rent-price ratio to evaluate economists both inside and outside academia may have been reticent to make any sort of predictions, for fear of damaging their reputations if they were wrong. 
housing markets is that for residential housing, renters' and buyers' markets are qualitatively distinct, so finding comparable properties proved challenging. Theoretical challenges also confronted work with price-income or price-rent ratios. Economic theory predicts that the level of interest rates should affect price-income and price-rent ratios, but researchers faced questions over the proper interest rates to use in their calculations. Finally, researchers using price-income or price-rent ratios were forced to take a stand on whether a deviation from a long-term trend reflected disequilibrium behavior, or simply a change in the equilibrium ratio itself. All of these issues made it difficult to mount a convincing counterargument at the time.

What about asset-price bubbles? While there is great interest in bubbles among research economists, the science of analyzing them remains primitive. The starting point for a formal analysis of bubbles is the standard idea taken from partial equilibrium analysis of individual choice that the amount someone should pay for something depends only on the market price and not on any link between that price and the notion of its fundamental underlying value. If the something is a financial asset, then the expected return is the key determinant for the investor and the investor correctly ignores the question of why that return is as high or low as it is when making decisions. In most contexts in economics, equilibrium - the invisible hand - ensures that the value of the asset is tied to its fundamentals, typically because a deviation from fundamentals would allow someone to make infinite profits. But in recent years, economists have constructed theoretical examples in which investors cannot, for one reason or another, bring prices into line with fundamentals and thus bubbles can persist. Matching such models with the real world, however, has proved problematic.

In Section II.B, we review the arguments of a prominent pessimist, Paul Krugman. Although his arguments were made in his widely read New York Times column rather than in a formal academic paper, Krugman, now a Nobel Prize-winning economist, has substantial credibility. He argued that because it is difficult to build in coastal areas of the United States, those areas are more "bubble-prone." Consequently, the rapid price increases on the coasts but not elsewhere were prima facie evidence that there was a bubble and that prices would eventually collapse.

It is tempting to call Krugman prescient because beginning in late 2006 prices did indeed crash. But his arguments were problematic both ex ante and ex post. Ex ante, it is unclear why Krugman thinks the coasts are more "bubble-prone." The models we have of asset-price bubbles do a reasonable job explaining why they can persist but have little to say about where we might expect them to start. As one prominent researcher in the field writes, "we do not have many convincing models that explain when and why bubbles start." ${ }^{5}$ Krugman's thesis seems to hinge on the idea that scarce coastal land is valuable and bubbles can only

\footnotetext{
${ }^{5}$ This quotation comes from the concluding paragraph of Brunnermeier (2008).
} 
happen when assets are in short supply, but the whole point about bubbles is that the fundamentals of supply and demand do not matter. Thus, there is no reason why land in places where it is easy to build could not experience bubbles. Ex post, as we will explore at length, the places in the United States where the housing market most resembled a bubble were Phoenix and Las Vegas. According to recent research, both locations are characterized by relatively high housing-supply elasticities; unlike certain coastal areas, the two cities have an abundance of surrounding land on which to accommodate new construction.

Ultimately, our paper argues that the academic research available in 2006 was basically inconclusive and could not convincingly support or refute any hypothesis about the future path of asset prices. Thus, investors who believed that house prices were going to fall could find evidence to support their position, while those who wanted to believe that house prices would continue to rise could not be dissuaded either. There were reasonable arguments on both sides.

We view a retrospective understanding of the real-time evolution of beliefs about the path of house prices as central to understanding the financial crisis of 2007-2009. Many lending decisions made during the housing boom seem daft in light of what happened. Why would lenders extend credit to borrowers with troubled credit histories, low (or no) down payments, or poorly documented incomes? Loans to these borrowers make sense for investors who are optimistic about the future trajectory of house prices, because even small amounts of positive appreciation protect mortgage investors from large losses. If house prices fall, however, then borrowers are likely to have negative equity, leaving them vulnerable to adverse life events like job loss that reduce their ability to make regular mortgage payments. In particular, owners with negative equity are unable to pay off their mortgages by selling their homes, so foreclosures often follow adverse life events. ${ }^{6}$ Gerardi et al. (2008) shows that the negative relationship between house price appreciation and mortgage losses was wellunderstood by market participants in 2006. Specifically, the paper shows that investors could and did understand that subprime loans in particular carried a high degree of risk if house prices fell. Other work, such as Foote et al. (2009), shows that prime loans, while generally less risky than subprime loans, were also adversely affected by the unexpected decline in housing prices. Thus, understanding the sources of optimism about house prices in 2006 in light of the catastrophe that followed is more than an exercise in the history of economic thought. Rather, it is a starting point toward an understanding of the role that economic theory and the pronouncements of economists might have played in the biggest financial crisis since the Great Depression.

The remainder of the paper proceeds as follows. Sections II and III review the argument

\footnotetext{
${ }^{6}$ Falling house prices can also cause foreclosures if negative-equity borrowers believe that house prices will not recover in any reasonable length of time - the so-called "ruthless" or "strategic" default.
} 
made by housing-market pessimists and optimists, respectively. Section IV reviews the research of the agnostic economists. We conclude in Section V with a discussion of the challenges of forecasting house prices and of acting on those forecasts.

\section{The Housing Pessimists}

In this section, we focus on economists who took a strong position on the unsustainability of future house price growth. We start with some research that pointed to the existence of a housing bubble as early as 2002 and 2003, several years before housing markets peaked in the United States. We then review arguments advanced by Krugman and others that geographical differences in residential building restrictions were important in getting a bubble started.

\section{A. Early warnings on the U.S. housing market}

One of the first prominent housing pessimists was Dean Baker of the Center for Economic and Policy Research in Washington, who in 2002 wrote that:

In the absence of any other credible theory, the only plausible explanation for the sudden surge in home prices is the existence of a housing bubble. This means that a major factor driving housing sales is the expectation that housing prices will be higher in the future. While this process can sustain rising prices for a period of time, it must eventually come to an end. (Baker 2002, p. 116)

Baker (2002) focused on the price-rent ratio, the housing equivalent of the price-dividend ratio used to assess valuation in equity markets. ${ }^{7}$ According to standard theory, the price of an asset should be equal to the present value of the sum of expected future dividends. A housing asset's dividend is essentially the service flow that it provides (that is, the flow value of shelter), which is in turn roughly equal to the house's rental value. By this reasoning, the price-rent ratio (or its inverse) can be used as a measure of how close housing prices are to fundamentals.

Baker showed that from 1995 to 2002, U.S. housing prices, as measured by the OFHEO index, rose by almost 50 percent in nominal terms, an increase that was substantially greater than the increase in overall prices (that is, inflation) during the same period. Akin to Shiller's findings, Baker found that prior to 1995, changes in nominal house prices moved in tandem with overall prices, so that real house prices displayed no upward trend. The rise in the price

\footnotetext{
${ }^{7}$ Leamer (2002) conducted a price-rent ratio analysis for a few markets in California and came to mixed conclusions. He found the San Francisco Bay Area to be overvalued in the early 2000s, but concluded that prices in the Los Angeles market were more consistent with fundamentals.
} 
index in the seven-year period analyzed by Baker was also significantly greater than the rise in rents; the Bureau of Labor Statistics (BLS) rental index rose by roughly 10 percent in real terms during this seven-year period, while the house price index rose by almost 30 percent. This difference is consistent with the time-series pattern of the price-rent ratio we present in figure 1. Baker noted that the rental and house price indexes had diverged in the late 1970s and again in the late 1980s, when growth in housing prices outpaced growth in rents, but that both episodes were followed by periods in which housing prices declined relative to rents. In addition, he noted that the rental vacancy rate in 2002 was 9.1 percent - the highest rate on record since the Census Bureau had begun collecting the data. The large number of vacancies suggested some downward pressure on rents going forward.

In addition to the divergence between rents and prices in the U.S. housing market, Baker also called attention to changes in demographic trends that could put additional downward pressure on house prices. He noted that during the 1970s and early 1980s, housing grew from about 17 percent of consumption to more than 25 percent, in large part due to increased demand for housing from the first baby boom cohorts, who were then entering adulthood. From the early 1980s to the mid-1990s, the housing share of consumption remained relatively constant, consistent with the modest demographic changes taking place in the United States at that time. In the future, Baker argued, as the baby boomers entered retirement, housing demand-and hence prices — would likely fall. ${ }^{8}$

Finally, Baker discussed the role of interest rates in moving prices higher. As we will discuss in more detail below, many economists pointed to low interest rates as justifying higher housing prices, but Baker was skeptical of this claim. Nominal interest rates were indeed low in the early 2000s, as the Federal Reserve had adopted a loose monetary policy to combat the effects of the 2001 recession. However, Baker pointed out that nominal rates could not explain the divergence of housing prices from fundamentals, as it is the real interest rate (the difference between the nominal rate and expected inflation) that should influence prices. During the boom period, real mortgage interest rates did not seem to be significantly lower than their levels in the mid-1990s before the run-up in house prices began. To further illustrate the point, Baker noted that from the early- to late-1980s there was a large drop in nominal rates (from almost 15 percent in 1981 to approximately 9 percent in 1988) without a large divergence between the rental and price indexes.

Another important early study in the pessimist camp was the 2003 Brookings paper by Karl Case and Robert Shiller (2003). Its analysis can be separated into two parts. The first part consists of a state panel-data analysis of the fundamentals that should have driven the trajectory of U.S. housing prices from 1985 through 2002. The main focus is on the relationship between prices and income per capita, although population, employment,

\footnotetext{
${ }^{8}$ See also Mankiw and Weil (1989) on this point.
} 
unemployment rates, housing starts, interest rates, and debt-to-income ratios (DTIs) also enter into the regression models. The empirical findings did not provide conclusive evidence one way or the other regarding the stability of housing prices, relative to what the authors perceived to be housing-market fundamentals. In particular, the results were sensitive to the particular geographic regions considered. For example, ratios of house prices to income per capita were stable in the vast majority of states over the 18-year period, but in eight states, the price-to-income ratios displayed pronounced cyclical patterns. ${ }^{9}$ In those eight states, the other variables that proxy for housing-market fundamentals (besides income) added significant explanatory power to the house price panel regressions. However, in an out-ofsample forecasting exercise for those states, Case and Shiller found that the fundamentals significantly underpredicted the actual movements in housing prices. Thus, while there was some evidence of a potential bubble in these eight coastal states, the authors concluded from their empirical analysis that overall, U.S. housing prices tracked market fundamentals fairly well.

However, the authors came to a different conclusion in the second part of their paper, which consisted of a survey of recent homebuyers in Orange County (Los Angeles, CA), Alameda County (San Francisco, CA), Middlesex County (Boston, MA), and Milwaukee County (Milwaukee, WI) in 2003. The survey was virtually identical to a 1988 survey that Case and Shiller had conducted in the same areas, in which they found what they believed to be fairly strong evidence of a housing bubble at that time. After the 1988 survey, housing prices in many coastal areas fell dramatically, partially reversing the price gains of the midto-late 1980s. Relative to the 1988 survey, the results of the 2003 survey were somewhat mixed. The majority of homebuyers surveyed in 2003 reported that investment was a "major consideration" in their purchase, or that they at least "in part" thought of their housing purchase as an investment. Far fewer said that they were buying a house "strictly for investment purposes" as compared to 1988. In addition, while only a small fraction of borrowers believed that purchasing a house involved a great deal of risk in the 2003 survey, the perception of risk in 1988 was even smaller in three out of the four areas (Milwaukee being the one exception). The most striking result of the survey involved the respondents' expectations of future price appreciation. In both the 1988 and 2003 surveys, more than 90 percent of respondents expected an increase in prices over several years, with the average expected increase over the next year being extremely high (between 7.2 and 10.5 percent in 2003 and 6.1 and 15.3 percent in 1988). Expectations over a longer-term horizon (10 years) were even higher in all four cities, varying from 11.7 percent per year in Milwaukee to 15.7

\footnotetext{
${ }^{9}$ The volatile states, ordered alphabetically by region, were Connecticut, Massachusetts, New Hampshire, Rhode Island, New Jersey, New York, California, and Hawaii.
} 
percent in San Francisco in 2003. ${ }^{10}$ Given these survey findings, Case and Shiller concluded that while the indicators of a bubble were perhaps not as strong in 2003 as they were in 1988 (except in Milwaukee), they were still present. In their concluding remarks, Case and Shiller acknowledged that in the majority of states, home prices seemed to track well with housing-market fundamentals, yet they took the position that a bubble had likely formed:

Nonetheless, our analysis indicates that elements of a speculative bubble in single-family home prices - the strong investment motive, the high expectations of future price increases, and the strong influence of word-of-mouth discussionexist in some cities. For the three glamour cities we studied, the indicators of bubble sentiment that we documented ... remain, in general, nearly as strong in 2003 as they were in 1988. (p. 341)

\section{B. The role of building restrictions in housing pessimism}

Paul Krugman, among others, claimed that the geographic distribution of price increases in the boom years proved the existence of a bubble and the inevitability of a crash. In an August 8, 2005, column for the New York Times, Krugman wrote that with respect to housing supply, the United States was really two countries — "Flatland" and the "Zoned Zone":

In Flatland, which occupies the middle of the country, it's easy to build houses. When the demand for houses rises, Flatland metropolitan areas, which don't really have traditional downtowns, just sprawl some more. As a result, housing prices are basically determined by the cost of construction. In Flatland, a housing bubble can't even get started. But in the Zoned Zone, which lies along the coasts, a combination of high population density and land-use restrictions — hence "zoned" - makes it hard to build new houses. So when people become willing to spend more on houses, say because of a fall in mortgage rates, some houses get built, but the prices of existing houses also go up. And if people think that prices will continue to rise, they become willing to spend even more, driving prices still higher, and so on. In other words, the Zoned Zone is prone to housing bubbles. And Zoned Zone housing prices, which have risen much faster than the national average, clearly point to a bubble. (Krugman, "That Hissing Sound," New York Times)

\footnotetext{
${ }^{10}$ In an accompanying comment to the Case and Shiller paper, Quigley raises the possibility that the respondents did not understand the concept of compounding interest, and may have answered differently if the question had been framed in a slightly different manner.
} 
As the Krugman excerpt illustrates, it is easy to find individual cities (like New York and San Diego) that support a Flatland/Zoned Zone dichotomy. But a more systematic look at the data reveals a more complicated story. Many cities with highly elastic supply curves for housing also experienced rapid increases in prices, especially in the last few years of the housing boom (2002-2005). Moreover, there does not seem to be a negative correlation between the price increase of new homes and the number of new homes built during the boom, as a simple dichotomy would predict.

A recent paper by Saiz (2010) allows a precise look at the correlations between housingsupply elasticities and price increases during the recent U.S. housing boom. Saiz uses the unique geographic features of different metropolitan areas to construct exogenous housingsupply elasticities. Topographical features that limit new building projects include coastlines, large bodies of water near city centers, or land that is steeply sloped. By calculating the prevalence of these features for each large city in the United States, Saiz constructs housing-supply elasticities that do not rely on the (potentially endogenous) use of legal restrictions that limit the construction of new homes.

Saiz finds that his elasticity measure correlates strongly with changes in housing prices at the level of the metropolitan statistical area (MSA), a finding that we replicate in figure 2. On the vertical axes of each of the three panels in the figure is the percentage change in OFHEO-measured prices from a given time period (1995-2005, 1999-2002, and 2002-2005). ${ }^{11}$ The horizontal axes feature the Saiz elasticities for 92 U.S. cities that had populations greater than 500,000 as of $2000 .{ }^{12}$ As we might expect, cities with very high supply elasticities saw only small increases in housing prices during the three time periods. The two cities on the far right of each panel, with supply elasticities above 5, are Fort Wayne, IN (elasticity $=5.36$ ) and Wichita, KS (elasticity $=5.45)$. With elasticities so high, whatever demand increase these cities might have experienced resulted in more supply via new construction, not higher prices.

As we move to the left from these two points, price increases become more common. However, we do not have to move all of the way to the left to find large price increases; many cities with relatively high elasticities (above 1.5) also experienced substantial price increases during the housing boom. Figure 3 presents the same data as the previous figure, but restricts the sample to cities with elasticities of 3.0 or less. ${ }^{13}$ The fitted regressions lines in these panels also illustrate a negative correlation between supply elasticities and price

${ }^{11}$ The periods are measured from the fourth quarters of the given years, so the 1995-2005 span covers 1995:Q4-2005:Q4, etc.

${ }^{12}$ There are actually 95 U.S. cities that meet this population criterion. However, there are no OFHEO price indexes for Ventura, CA; Sarasota, FL; and Jersey City, NJ. Thus, the panels of figure 2 have only 92 data points each.

${ }^{13}$ This restriction generates a legible graph that includes the names of the remaining cities. Eleven cities are eliminated by this restriction, so each panel of figure 3 has 81 cities. 
increases. But these lines also leave a lot of variation unexplained. For example, in panel A of figure 3, which uses data from 1995:Q4 through 2005:Q4, the $R^{2}$ of the regression line is only 0.42. The corresponding $R^{2}$ for panel B (1999:Q4-2002:Q4) is 0.29, while that for Panel C (2002:Q4-2005:Q4) is 0.30. ${ }^{14}$

The takeaway point from figure 3 is that house price increases occurred in many cities where new construction could have occurred with relative ease. We can press this point further by noting that new construction did in fact occur in areas that also had large price increases. For this analysis, we switch to annual state-level data, due to inconsistences in the reporting of building permits at the city level. ${ }^{15}$ Figure 4 presents a scatterplot of state-level increases in OFHEO house prices from the three periods against increases in new building permits. ${ }^{16}$ Krugman's Flatland/Zoned-Zone theory, combined with a uniform increase in demand across the different states, would predict a negative relationship between price increases and construction. Yet there is little evidence of a negative correlation in this graph. In unreported regressions, we found that the raw correlations between price increases and new construction were actually often positive, though these correlations often declined to insignificance in regressions where state-level unemployment rates were also included.

Of course, raw correlations between highly endogenous variables like house prices and new construction do not provide airtight evidence for any particular theory of the housing market. But such correlations can provide evidence against theories that predict different correlations. Simply put, it is hard to tell a story that during the housing boom, the main driver of differential price increases across states was varying supply elasticities combined with a uniform increase in demand. It appears that some states with abundant land, like Arizona, Nevada, and Florida, experienced much larger increases in demand than other states, including those located on the coasts. ${ }^{17}$

Do our findings suggest that Krugman was mistaken to point to differential price increases in support of the bubble story? Not at all. For one thing, it is true that as a general matter, price-inelastic cities like New York and Boston saw higher house price increases than did price-elastic cities like Fort Wayne and Wichita. More to the point, however, one could argue that big price increases in elastic cities like Las Vegas and Phoenix provided even

\footnotetext{
${ }^{14}$ Including the square of the Saiz elasticity raises the $R^{2}$ by less than 0.04 in all cases. Linear regressions that include all 92 cities in figure 2 have $R^{2}$ s of 0.39 (1995-2005), 0.30 (1999-2002), and 0.32 (2002-2005).

${ }^{15}$ We found that tabulations of city-level building permits were less consistent than the price data from OFHEO, due to definitional changes for metropolitan areas that occurred in the mid-2000s (which is our main period of interest). Nevertheless, we investigated the relationship between new construction and priceincreases for about 70 cities that we could match. Our results were consistent with the state-level evidence presented here.

${ }^{16}$ The absolute changes in building permits are divided through by the state's initial population.

${ }^{17}$ Davidoff (2010) makes a similar point, but does not use the Saiz elasticities. He shows that coastal markets saw greater average price growth during the boom, but did not experience greater crashes or greater volatility than non-coastal areas, where supply elasticities are assumed to be larger.
} 
stronger evidence that bubble psychology had gripped the market. Due to abundant surrounding land, Las Vegas and Phoenix had been long able to accommodate large numbers of new migrants without big increases in house prices. The fact that some people became willing to buy houses in these cities at prices far above construction costs, especially after 2002, is perhaps a signal that price expectations had become irrational. Unfortunately, the uneven pattern of price increases we find across U.S. cities was interpreted differently by the anti-bubble camp. This group sometimes conceded that prices in some cities had gotten out of line, but argued that a few overheated markets do not necessarily reflect a national housing bubble. Indeed, as a general matter, geographic differences in house price appreciation played a large role in the writings of many anti-bubble economists. We turn to a detailed analysis of these arguments in the next section.

\section{The Housing Optimists}

Some economists expressed deep skepticism about the possibility of a bubble and went on the record in stating that they did not expect house prices to fall:

As of the end of 2004, our analysis reveals little evidence of a housing bubble. In high-appreciation markets like San Francisco, Boston and New York, current housing prices are not cheap, but our calculations do not reveal large price increases in excess of fundamentals. For such cities, expectations of outsized capital gains appear to play, at best, a very small role in single-family house

prices. Rather, recent price growth is supported by basic economic factors such as low real long-term interest rates, high income growth and housing price levels that had fallen to unusually low levels during the mid-1990s. (Himmelberg, Mayer, and Sinai 2005, p. 68)

This quotation comes from the introduction of Himmelberg, Mayer, and Sinai (2005), which became perhaps the most widely cited evidence against a housing bubble upon its publication. The authors offered a persuasive critique of the usual measures marshalled by pro-bubble advocates, including the price-rent ratio and price-income ratio. Himmelberg, Mayer, and Sinai based their analysis on the more formal "user cost of housing" concept, which recognizes that the cost of owning a house reflects more than the purchase price of the property. For example, other variables that affect the cost of ownership include tax benefits (like the mortgage interest deduction), property taxes, maintenance costs, anticipated capital gains, opportunity costs, and the risk of large capital losses. Thus, studying the ratio of rental costs to ownership costs is a more theoretically sound way to investigate whether a bubble may exist than by investigating the ratio of rents to house prices. We can 
write such a relationship as follows:

$$
R_{t}=P_{t} \cdot \mu_{t}
$$

where $\mu_{t}$, the user cost of housing, is defined as

$$
\mu_{t}=r_{t}^{r f}+\omega_{t}-\tau_{t}\left(r_{t}^{m}+\omega_{t}\right)+\delta_{t}-g_{t+1}+\gamma_{t}
$$

In this expression, $r_{t}^{r f}$ is the one-year, risk-free interest rate, $\omega_{t}$ is the one-year cost of property taxes, the term $\tau_{t}\left(r_{t}^{m}+\omega_{t}\right)$ represents the tax deductibility of mortgage interest and property taxes (for those that itemize their returns), $\delta_{t}$ reflects maintenance costs, and $g_{t+1}$ is the expected capital gain over a one-year horizon. ${ }^{18}$ Finally, $\gamma_{t}$ is a risk premium, reflecting the higher risk of owning versus renting.

Equation 1 tells us that the price-rent ratio equals the inverse of the user cost $\left(\frac{1}{\mu_{t}}\right)$, so variation in the price-rent ratio should reflect variation in the user cost of housing. Himmelberg, Mayer, and Sinai (2005) made the correct point that simply looking at timeseries variation in price-rent ratios, or cross-sectional differences in these ratios, without considering possible variation in user costs is misleading and could not shed light on the bubble question.

The right thing to do is to work with careful estimates of user costs in various cities, so the authors constructed measures of user costs for 46 metropolitan areas from 1980 through 2004. Himmelberg, Mayer, and Sinai compared differences in user costs across cities, as well as changes in user costs over time within a city. Their first observation was that user costs can vary greatly across U.S. cities. The highest user-cost market (Pittsburgh) had user costs that were more than double that of the lowest user-cost market (San Jose). In addition, user costs were falling over time, and by 2004 were below their long-run averages in most cities. According to equation 1, declining user costs imply rising price-rent ratios. Consequently, the increasing price-rent ratios used as evidence to support a bubble actually reflected, in large part, changes in user costs and thus in fundamentals. ${ }^{19}$

To make their analysis more precise, the authors then compared the ratio of imputed rent (calculated by multiplying their user cost estimates by the OFHEO house price index) to actual rent (the BLS index) in 2004 to its 25-year average in each city (figure 2 in their paper). In the vast majority of cities they found the ratio in 2004 to be very close to or

\footnotetext{
${ }^{18}$ The $g_{t+1}$ term is negative if capital losses are expected.

${ }^{19}$ In this exercise the authors were not comparing user costs across cities, but were only looking at trends within cities over a 25-year period. In this exercise variation in user costs does not come from assumptions about cross-city variation in expected capital gains (the $g_{t+1}$ term), as the authors set expected capital gains in each city to the one-year average realized return calculated over the entire 25-year period. Thus, by assumption, there was no variation in expected capital gains across cities.
} 
below its 25-year average. Moreover, the cities in which the ratio in 2004 was substantially above its average were not places that had experienced rapid price appreciation (Detroit, Milwaukee, Minneapolis, and so on). The authors also constructed the ratio of imputed rent to per capita income as an alternative measure of housing valuations, and came to a similar set of conclusions: the ratio in 2004 was below its 25-year average in most cities in their sample.

Another study that took a skeptical view of the housing bubble was McCarthy and Peach (2004). The paper analyzed the arguments in support of a housing bubble, and concluded that there was very little credible evidence:

Our main conclusion is that the most widely cited evidence of a bubble is not persuasive because it fails to account for developments in the housing market over the past decade. In particular, significant declines in nominal mortgage interest rates and demographic forces have supported housing demand, home construction, and home values during this period. Taking these factors into account, we argue that market fundamentals are sufficiently strong to explain the recent path of home prices and support our view that a bubble does not exist. (p. 2)

The authors' first argument was that the most popular types of house price indices used at the time - repeat-sales indices and median price indices - were not very accurate in measuring the value of the U.S. housing stock. Median price indices had the most severe problems. According to McCarthy and Peach, median price indices are too volatile in the short run because the composition of sales fluctuates substantially from month to month. Moreover, the pricing data used to construct the indices reflect only recent sales transactions, so they are likely not very representative of the nation's entire housing stock. The repeat-sales indices largely solve these issues, but even these measures cannot control for changes in the quality of the housing stock over time due to depreciation or renovations.

As an alternative price index, the authors advocated the constant-quality new-home price index that is published by the U.S. Bureau of the Census. This is a hedonic index that accounts for changes in the quality of homes over time. ${ }^{20}$ Compared to the other price indices, the Census Bureau series showed significantly less home price appreciation over the authors' sample period (1977-2003). The implication was that a significant portion of the house price appreciation measured using the median price and repeat-sales indices was attributable to quality increases. When the authors used the hedonic constant-quality index instead of the repeat-sales index to calculate a time series of the aggregate price-rent ratio,

\footnotetext{
${ }^{20} \mathrm{~A}$ hedonic index is constructed by regressing sale prices on various housing and neighborhood characteristics.
} 
they found much less support for a housing price bubble. ${ }^{21}$

The paper then pointed out a list of shortcomings with respect to the most common statistics used by proponents of the housing bubble perspective: the price-to-income ratio and the price-rent ratio. According to McCarthy and Peach, the first significant drawback of the two statistical series is that they ignore the effect of nominal interest rates. As we discuss below, decreases in nominal interest rates make homeownership more affordable for borrowing-constrained households. Lower nominal rates also lower the opportunity cost of homeownership, as these rates imply lower yields on competing assets. ${ }^{22}$ To support their argument, the authors pointed out that from 1990 to 2003, the decline in nominal interest rates resulted in a 130-percent increase in the maximum mortgage debt for which a family earning the median U.S. household income could qualify, using a then-standard maximum debt-to-income ratio of 27 percent. ${ }^{23}$

Finally, McCarthy and Peach used a stylized structural model of the housing market in order to compare predicted equilibrium prices from the model with actual prices in the data. They then decomposed price changes into contributions from growth factors such as income and consumption, as well as from user-cost declines largely due to interest rate movements. According to the model, housing prices were expected to appreciate in the late 1990s and early 2000s, in large part because of a substantial decline in user costs induced by declining interest rates over the period. But more significant is their finding that the model's predicted prices were greater than actual prices at the end of the sample period, leading the authors to conclude that U.S. house prices during this period were actually lower than what the fundamentals would justify.

John Quigley is another well-respected real estate economist who was highly skeptical that a housing bubble was present. Along with Christopher Mayer, he was tasked with providing formal comments to the Brookings paper written by Case and Shiller (2003). In those comments (Quigley 2003), he discussed numerous reasons for skepticism regarding how they interpreted their survey results. In addition, Quigley listed eight specific reasons for questioning the existence of a housing bubble in 2003. First, he pointed to Case and Shiller's finding of a stable co-movement of income and house prices for the large majority of U.S. states. Second, in an argument similar to that of Himmelberg, Mayer, and Sinai (2005), Quigley pointed out that the user cost of housing in the United States had been trending downward since the early 1980s. Third, Quigley noted that demographic trends would

\footnotetext{
${ }^{21}$ See chart 7 in McCarthy and Peach (2004).

${ }^{22}$ In standard versions of asset-pricing theory, which do not include borrowing constraints, the real interest rate, not the nominal rate, should matter for housing valuations. Whether the real or the nominal interest rate matters more in practice is a topic we return to below.

${ }^{23}$ This is the same argument that Mayer (2003) discussed in his effort to rationalize a role for nominal rates in house price increases (although he was skeptical of this channel). We discuss this argument in more detail below.
} 
probably increase the demand for housing in the United States, a claim that stood in contrast to the discussion in Baker (2002). ${ }^{24}$ Fourth, Quigley wrote that the continued desirability of the amenities available in many coastal cities, along with the inelasticity of housing supply in those areas, would put continued upward pressure on prices in many cities. ${ }^{25}$ Fifth, Quigley noted the severe downward rigidity in nominal housing prices, which would make large nominal price declines unlikely. Sixth, Quigley claimed that high transactions costs in housing markets would tend to decrease the amount of speculation and trading volume. Seventh, like McCarthy and Peach (2004), Quigley noted the inability of popular house price indices to capture the increasing quality of American homes. Finally, Quigley emphasized the point that U.S. housing markets are local, so the imperfect correlation across local housing markets would make a large national price decline unlikely.

Of all the pre-crisis papers that were skeptical of the housing bubble, perhaps Smith and Smith (2006) was the most adamant. The paper used a net present value (NPV) framework to calculate the fundamental value of housing in various areas across the United States. The valuation framework employed was based on the ideas that underpin much of the price-rent analysis discussed above. The starting point is that a house, like any other traded asset, can be valued by calculating the projected stream of future service flows, discounted by an appropriate rate of return. However, unlike a stock, which has only future cash dividends, the future service flows associated with homeownership come from many sources. Some of these flows are largely observable financial variables. Examples include the imputed rent net of mortgage payments, as well as expenses such as maintenance costs and property taxes. Yet the service flows to homeownership also include unobservable nonfinancial benefits, such as privacy and the discretion to modify the property. According to this framework, a homebuyer should be able to use projected cash flows and an assumed required rate of return to determine whether the NPV of homeownership is positive or negative. If it is positive, then purchasing the house is a worthwhile investment; if it is negative, renting is the more attractive option. Smith and Smith focus most of their analysis on calculating internal rates of return (IRRs), which are defined as the rates of return that would make NPVs zero. Equivalently, these IRRs are the rates of return that would make potential buyers indifferent between owning and renting.

Smith and Smith's innovation was to obtain estimates of the imputed rent of owneroccupied properties, which are by definition unobservable. This calculation was made possible using matched data on rental properties in areas with owner-occupied houses of

\footnotetext{
${ }^{24}$ Unlike Baker, who argued that the baby boomers would likely downsize their homes as they crossed the retirement threshold, Quigley argued that they would "continue to resist downsizing" (p. 357).

${ }^{25}$ Note the contrast with Krugman on this point. Quigley saw higher prices in coastal areas as evidence that prices were in line with fundamentals, while Krugman argued that coastal areas were more bubbleprone.
} 
similar quality. Thus, the authors could obtain relatively precise estimates of the rental income that the owner-occupied houses would command if they were placed on the rental market. Their data included 10 U.S. markets representative of both the Flatland and the Zoned Zone: Atlanta, Boston, Chicago, Dallas, Indianapolis, Los Angeles County, New Orleans, Orange County, San Bernardino County, and San Mateo County. The results of their IRR calculations were striking. Only one of the markets (San Mateo County) appeared to be significantly overpriced at the time the paper was written. Moreover, even some widely perceived bubble areas - such as Boston, Chicago, and San Bernardino County - were significantly underpriced relative to the estimated fundamental values.

\section{The Housing Agnostics}

As we explained in the introduction, the most prevalent view among economists in the precrisis period was an unwillingness to make strong predictions about the future path of U.S. housing prices. We first turn to Mayer (2003), who investigated the role of real and nominal interest rates in the determination of housing prices. Two important empirical findings in this paper are, 1) that real mortgage rates were actually higher in the early 2000s than they were in the 1970s, and not significantly lower compared to their levels in the 1990s (figure 3 in Mayer 2003), and 2) that estimates from historical data do not show large correlations between real interest rates and housing prices. Given these results, Mayer pointed toward low nominal rates as perhaps the only rational explanation for the increase in housing prices during the 2001 recession, though he recognized that standard theory predicts that real and not nominal rates should influence housing demand. One way in which nominal prices could matter, Mayer wrote, is if target payment-to-income ratios were important in the housing market. If there was some maximum payment-to-income ratio that lenders refused to exceed for a significant fraction of potential borrowers, then this constraint would essentially be relaxed if the nominal mortgage rate fell. The demand for housing would therefore increase, and prices would rise. However, Mayer was skeptical about this channel, stating:

There are many reasons to be skeptical of a model in which demand for housing is generated by a fixed payment-to-income ratio. For example, this model clearly does not hold when one examines cross-sectional data for U.S. metropolitan areas, which show that consumers do not have a fixed ratio of housing costs to income. Evidence suggests that homeowners and renters spend a higher percentage of income in high-priced areas like San Francisco than in low-priced ones like Milwaukee. So, at least cross-sectionally, this theory does not hold. Whether it is true within metropolitan areas, one could make some arguments. Although it is hard to believe in a target payment-to-income ratio completely, it is the only 
model that I can come up with that predicts that lower nominal interest rates will lead to higher home prices. (p. 352)

Haines and Rosen (2007) found evidence that a measure of housing affordability, driven in large part by changes in nominal mortgage interest rates, was, in fact, an important determinant of U.S. housing prices in the period 1980-2006. The paper estimated a reducedform regression of housing prices on a number of housing supply and demand determinants including an "affordability index," defined as the ratio of median household income to the annual payment on a fixed-rate, 30-year, $\$ 100,000$ mortgage with a 20 percent down payment. The affordability index rises with either an increase in household income or a decrease in the nominal mortgage rate, as these movements make it easier for a household to buy a home at any given price. The authors pooled data across the largest 43 MSAs and found that the affordability index was a significant determinant of movements in housing prices over time and price differences across markets. ${ }^{26}$

In addition to their focus on the relationship between affordability and house prices, Haines and Rosen (2007) also attempted to shed light on whether a bubble existed in the national housing market. On the one hand, they noted that most of the academic literature had taken a skeptical view of bubble claims, writing:

The general consensus of the academic literature is that home prices are largely in line with fundamentals. Overpriced markets, if any, are limited in number and in the scope of overpricing. (p. 18)

However, the authors also pointed out that many non-academic studies had firmly concluded a bubble existed; a key example is a study by Global Insight and National City Corporation (2006). Haines and Rosen (2007) hypothesized that the difference was due to the use of more recent data in non-academic research. The publication lag in scholarly journals meant that many recent academic papers had not made use of data from 2005 and 2006, a period which was beginning to show a softening in the national housing market. For their part, Haines and Rosen (2007) ran house-price regressions on data through 2006, using the predicted values from these regressions as proxies for fundamental housing prices. They then compared these predictions to actual prices at the end of the sample period. Results were mixed. In many markets, actual 2006 prices were below predicted prices, while in some other markets, actual prices were 10 to 20 percent above their predicted values. The authors noted that the MSAs that seemed to be the most overvalued according to the model (for example, New York and San Francisco) had generally been more volatile than the majority of U.S. markets, so the authors downplayed the significance of these findings somewhat. At the end of the day,

\footnotetext{
${ }^{26}$ The $R^{2}$ of a univariate regression was 0.76 .
} 
the authors did not interpret their empirical work as strong evidence for either side of the bubble debate.

Krainer and Wei (2004) was one of the pre-crisis studies that focused on the pricerent ratio. A key contribution of this paper was to study the price-rent ratio for housing using statistical techniques that had been developed to model the price-dividend ratio for stocks. ${ }^{27}$ Previous stock-market research had pointed out that the price-dividend ratio could be decomposed into two terms, one that reflected expected growth in dividends and another that reflected expected future discount rates (or, equivalently, the rates of return that future investors would require). If dividends were expected to rise sharply in the future, or if we expected future discount rates to be low, then we would predict that the today's price-dividend ratio would be high. Conversely, if dividends were expected to fall, or if we thought that future investors would discount income highly, then investors today would be unwilling to pay high prices for stocks. The current price-dividend ratio would therefore be low. One crucial issue in this line of research is that discount rates are unobservable. Consequently, researchers often proxied for required rates of return with the actual rates of return observed in the stock market. In particular, the required rate of return from period $t$ to $t+1$ was set equal to the sum of the dividend yield in period $t$ and the capital gain in the stock price between periods $t$ and $t+1$.

To apply this methodology to the housing market, Krainer and Wei constructed a timeseries of the price-rent ratio at the national level going back to the early 1980s. The numerator of this ratio was the repeat-sales existing house price series from OFHEO. The owner's equivalent rent series from BLS was used for the denominator. ${ }^{28}$ The authors then decomposed their price-rent series into movements in future returns (that is, movements in the proxy for future discount rates) and movements in rent growth. Because this exercise used actual future values of dividend growth and rates of return to proxy for expected future values of these two variables, they could not decompose movements in the price-rent ratio at the end of the sample, because not enough future values of rents and returns were available.

Krainer and Wei reported two main findings. First, they found that future rents and returns did a reasonable job of explaining the total variation in the price-rent ratio. In other words, the price-dividend decomposition originally developed to explain the stock market did a good job of explaining patterns in the housing market as well. Second, the authors found found that most of the movements in the price-rent ratio could be explained by movements in required rates of return, rather than movements in rents. ${ }^{29}$

\footnotetext{
${ }^{27}$ See, for example, Campbell and Shiller (1988) and Cochrane (1992).

${ }^{28}$ Krainer and Wei found that this ratio had substantially increased in the early 2000s after having been roughly flat over the previous 15 years. As we saw in figure 1, there was a dramatic rise in the price-rent ratio from around 1.0 in the late 1990s to nearly 1.4 by 2006 .

${ }^{29}$ This result is similar to what Cochrane (1992) found in a decomposition of the price-to-earnings ratio in equity markets.
} 
What did these results imply about the possibility of a bubble in the housing market? On one level, the authors were comforted by the fact that a rational model based on fundamental factors like future rents and discount factors explained much of the historical variation in the price-rent ratio. "Put another way," the authors wrote, "other factors, such as bubbles, do not appear to be empirically important for explaining the behavior of the aggregate price-rent ratio" (p. 3). Yet the authors had mixed feelings about whether a bubble existed in the current market. Like other researchers, Krainer and Wei used actual returns to proxy for the unobserved discount rates. These returns included capital gains, which are simply changes in prices. Thus, the statement that future discount rates were likely to explain the high price-rent ratio during the housing boom was really a statement that future prices should be expected to move in ways that were unrelated to rents. Specifically, houseprice appreciation should slow down, reflecting the lower discount rates required by future investors. These lower discount rates, in turn, could justify the high level of the price-rent ratio at the time the article was written. Of course, there would be no way to know for sure whether movements in future prices had anything to do with future discount rates, because the discount rates are unobservable. All in all, while the model could conceivably explain movements in housing's price-rent ratio in the past, there were no observable factors that conclusively proved that the current price-rent ratio did not reflect a bubble. The model could only point out how future prices would be expected to move if a bubble did not exist.

Gallin (2008) also provided a technical analysis of house prices and rents, focusing on the rent-price ratio (which, of course, is simply the inverse of the price-rent ratio discussed above). To construct this ratio, Gallin used a repeat-sales index developed by Freddie Mac and a price index for tenants' rent from the BLS. ${ }^{30}$ The sample period was 1970 through 2003; while Gallin's paper was published in 2008, the first draft of the paper was completed in 2004 and the data was not updated in the intervening time period. The paper focused on determining how well the rent-price ratio predicts future changes in real rents and house prices. Gallin's first finding was that there is a stable long-run relationship between house prices and rents (or, more formally, that rents and prices are cointegrated over the sample period). Given this finding, he estimated an error-correction model (ECM) to determine how rents and prices fluctuate in the short-run around their stable long-run relationship. The ECM model estimates suggested that rents and prices both correct back toward each other, but the findings were inconclusive because the estimates were imprecise. Gallin then turned to an analysis of long-horizon regressions (as opposed to the higher frequency ECM). Specifically, he tested the hypothesis that the rent-price ratio predicts future movements of rents and house prices over a three-year horizon. The data showed that periods of low

\footnotetext{
${ }^{30}$ Gallin used the tenant's rent index as opposed to the owner's equivalent rent index because of the former's superior time series coverage.
} 
rent-price ratios were followed by periods where real rent growth was faster than usual, and real house price growth was slower than usual. ${ }^{31}$ This observation is consistent with the finding of mean-reversion from the ECM estimates. In addition, the response of house prices to the rent-price ratio in returning to the long-run relationship was found to dominate the response of rents.

Gallin concluded that it was reasonable to use the rent-price ratio as a measure of valuation and a gauge for housing price fundamentals. But he was disinclined to interpret the rapid decline in the ratio at the end of his sample period as conclusive evidence of a bubble:

Because a low rent-price ratio has been a harbinger of sluggish price growth since 1970 , it seems reasonable to treat the rent-price ratio as a measure of valuation in the housing market. Indeed, one might be tempted to cite the currently low level of the rent-price ratio as a sign that we are in a house price "bubble." However, several important caveats argue against such a strong conclusion and in favor of future research. (p. 19)

The caveats included potential measurement error in rents and house prices, concerns that the theory motivating the empirical work was too simplistic and ignored important issues like risk and transactions costs, and misgivings over relying too much on any particular statistic to provide out-of-sample forecasts of a volatile and notoriously unpredictable asset price.

Davis, Lehnert, and Martin (2008) constructed the longest time series of rent-price ratios (to our knowledge), using the Decennial Census of Housing (DCH) to obtain data going all the way back to 1960. The authors used the DCH to construct five benchmark estimates of the average rent-price ratio for the stock of owner-occupied housing. ${ }^{32}$ They then used quarterly rent and price indexes (BLS tenants' rent index and the Freddie Mac repeat-sales index) to interpolate rent and price data between the $\mathrm{DCH}$ years and to extrapolate the data beyond 2000. They found that between 1960 and 1995, the rent-price ratio fluctuated in a relatively narrow range of between 5.0 and 5.5 percent (except for a brief period in the early 1970 s when it rose to approximately 6.0 percent). In the period 1995-2006, however, the ratio declined sharply, to a historical low of 3.5 percent. The authors speculated that this dramatic decline could have occurred because of a drop in the discount rate on housing dividends (rents), because of an increase in expected future capital gains, or both. They concluded that a return of the rent-price ratio to its historical average would likely require a modest decline in housing prices:

\footnotetext{
${ }^{31}$ In these regressions, Gallin controlled for the user cost of housing.

${ }^{32}$ They estimated imputed rents using data on rental properties and a hedonic regression technique to map the rental property data to owner-occupied houses.
} 
If the rent-price ratio were to rise from its level at the end of 2006 up to about its historical average value of 5 percent by mid-2012, house prices might fall by 3 percent per year, depending on rent growth over the period. (p. 280)

This quote summarizes the views of the agnostics quite nicely. Despite finding fairly convincing evidence that the U.S. housing market was overvalued in 2004-2006, they were unwilling to take a strong position on the existence of a housing bubble for various reasons, including a lack of confidence in the data and ambiguity regarding the predictions of economic theory.

\section{House Price Forecasts and Public Policy}

From our review of the pre-crisis housing literature from the early-to-mid-2000s, it is apparent that well-trained and well-respected economists with the best of motives could and did look at the same data and come to vastly different conclusions about the future trajectory of U.S. housing prices. This is not such a surprising observation once one realizes that the state-of-the-art tools of economic science were not capable of predicting with any degree of certainty the collapse of U.S. house prices that started in 2006. The asset-pricing literature does not yet have a firm grasp on when and why prices can deviate from market fundamentals for long periods of time. Even the best models have a difficult time explaining many of the extremely large movements in asset prices that have characterized our financial markets in the past, including the stock-market crashes of 1929, 1987, and 2000-2002. One wonders how market participants might have responded to a consensus in the economics profession that housing prices were unsustainable, meaning that highly leveraged bets on housing would be likely to end disastrously. But as this paper shows, market participants were never forced to respond to such a consensus because consensus did not exist.

While the assumption that asset markets are efficient in an informational sense has undoubtedly improved our understanding of financial markets in many ways, it appears that large and systematic departures from efficiency can and do take place. Concerns that realworld asset markets can be subject to irrational exuberance has been heightened by the results of laboratory experiments, where bubbles often form in artificial trading environments. Smith, Suchanek, and Williams (1988), a seminal paper in this field, documented that bubbles arose in controlled experiments in which participants had full knowledge of the environment, including the intrinsic dividend value of the asset. In a more recent study, Haruvy, Lahav, and Noussair (2007) followed the same methodology, and not only veri-

fied the existence of bubbles in controlled settings, but also found substantial evidence of adaptive expectations: 
We find that individuals beliefs about prices are adaptive, and primarily based on past trends in the current and previous markets in which they have participated. Most traders do not anticipate market downturns the first time they participate in a market, and, when experienced, they typically overestimate the time remaining before market peaks and downturns occur. (p. 1901)

One of the more positive aspects of their study was the finding that bubbles are much less likely to occur as traders become more experienced. However, in a follow-up study, Hussam, Porter, and Smith (2008) showed that this experience effect is not robust to changes in the underlying environment:

$[\mathrm{I}] \mathrm{n}$ order for price bubbles to be extinguished, the environment in which the participants engage in exchange must be stationary and bounded by a range of parameters. Experience, including possible "error" elimination, is not robust to major new environment changes in determining the characteristics of a price bubble. (p. 924)

These findings seem especially relevant to the experience of housing markets both in the United States and around the world over the past decade. The expansion of housing credit to previously underserved segments of the U.S. population (that is, to subprime borrowers) meant an influx of new, and potentially less financially sophisticated housing-market participants. In addition, the introduction and widespread use of more complicated structured finance products, like the many types of collateralized debt obligations (CDOs), implied a rapidly changing menu of financial products.

The evolving landscape of mortgage lending is also relevant to an ongoing debate in the literature about the direction of causality between reduced underwriting standards and higher house prices. Did lax lending standards shift out the demand curve for new homes and raise house prices, or did higher house prices reduce the chance of future loan losses, thereby encouraging lenders to relax their standards? Economists will debate this issue for some time. For our part, we simply point out that an in-depth study of lending standards would have been of little help to an economist trying to learn whether the early-to-mid 2000s increase in house prices was sustainable. If one economist argued that lax standards were fueling an unsustainable surge in house prices, another could have responded that reducing credit constraints generally brings asset prices closer to fundamental values, not farther away.

In our view, understanding the ways in which economists try to understand asset prices in real time is critically important with regard to the direction of future policy. First, it should give substantial pause to those who believe we can eliminate the formation of bubbles by simply curbing corruption and by imposing more regulation on markets. Since bubbles 
arise even in the most controlled environments, we may need to acknowledge that we do not currently have the ability to prevent a bubble from forming or the ability to identify a bubble in real time. Instead, we could focus on ensuring that potential homeowners and investors understand the risks associated with their investments, and take necessary precautions against such declines. If we have learned anything from this crisis, it is that large declines in house prices are always a possibility, so regulators and policymakers must take them into account when making decisions. A 30 percent fall in house prices over three years may be very difficult, if not impossible, to generate in any plausible econometric model, but a truly robust financial institution must be able to withstand one. The fact that so many professional investors as well as individual households ignored this possibility, even in 2006, suggests that we cannot allow investors to try to time market collapses.

Finally, individual homeownerships should also be robust to significant declines in housing prices. A standard way to do this is by requiring a substantial downpayment, which reduces the probability of negative equity when prices fall. In the future, robustness might also be enhanced by requiring the purchase of insurance against house price declines, a financial product made at least theoretically possible by the development of new markets in house price risk. At the very least, any policy that encourages buyers to take on loans with low downpayments deserves to be evaluated carefully, given the sharp decline in house prices we have recently experienced. 


\section{References}

Baker, Dean. 2002. "The Run-Up in Home Prices: A Bubble." Challenge 45 (6): 93-119.

Brunnermeier, Markus K. 2008. "Bubbles." In The New Palgrave Dictionary of Economics, edited by Steven N. Durlauf and Lawrence E. Blume, Second Edition. Basingstoke: Palgrave Macmillan. Available at http://www.dictionaryofeconomics.com/article?id= pde2008_S000278.

Campbell, John Y., and Robert J. Shiller. 1988. "The Dividend-Price Ratio and Expectations of Future Dividends and Discount Factors." The Review of Financial Studies 1 (3): 195-228.

Case, Karl E., and Robert J. Shiller. 2003. "Is There a Bubble in the Housing Market?" Brookings Papers on Economic Activity 2003 (2): 299-342.

Cassidy, John. 2002. "The Next Crash." The New Yorker, November 11. Available at http://www.newyorker.com/archive/2002/11/11/021111fa_fact_cassidy.

Cochrane, John H. 1992. "Explaining the Variance of Price-Dividend Ratios." The Review of Financial Studies 5 (2): 243-280.

Davidoff, Thomas. 2010. "Supply Elasticity and the Housing Cycle of the 2000s." Working Paper. Sauder School of Business, University of British Columbia. Available at http: //strategy.sauder.ubc.ca/davidoff/shark.pdf.

Davis, Morris, Andreas Lehnert, and Robert Martin. 2008. "The Rent-Price Ratio for the Aggregate Stock of Owner-Occupied Housing." Review of Income and Wealth 54 (2): 279-284.

Foote, Christopher L., Kristopher Gerardi, Lorenz Goette, and Paul S. Willen. 2009. "Reducing Foreclosures: No Easy Answers." NBER Macroeconomics Annual 22:89138.

Gallin, Joshua. 2008. "The Long-Run Relationship Between House Prices and Rents." Real Estate Economics 36 (4): 635-658.

Gerardi, Kristopher, Andreas Lehnert, Shane M. Sherlund, and Paul Willen. 2008. "Making Sense of the Subprime Crisis." Brookings Papers on Economic Activity 2008 (Fall): $69-145$.

Global Insight and National City Corporation. 2006. "House Prices in America: Valuation Update for the 2nd Quarter of 2006." Available at www.globalinsight.com/gcpath/ Q22006report.pdf. 
Haines, Cabray L., and Richard J. Rosen. 2007. "Bubble, Bubble, Toil, and Trouble?" FRB Chicago Economic Perspectives. Available at http://www.chicagofed.org/digital_ assets/publications/economic_perspectives/2007/ep_1qtr2007_part2_haines_rosen.pdf.

Haruvy, Ernan, Yaron Lahav, and Charles N. Noussair. 2007. "Traders' Expectations in Asset Markets: Experimental Evidence." American Economic Review 97 (5): 19011920.

Himmelberg, Charles, Christopher Mayer, and Todd Sinai. 2005. "Assessing High House Prices: Bubbles, Fundamentals, and Misperceptions." Journal of Economic Perspectives 19 (4): 67-92.

Hussam, Reshmaan N., David Porter, and Vernon L. Smith. 2008. "Thar She Blows: Can Bubbles Be Rekindled with Experienced Subjects?" American Economic Review 98 (3): 924-937.

Krainer, John, and Chischen Wei. 2004. "House Prices and Fundamental Value." FRBSF Economic Letter, no. 2004-27. San Francisco: Federal Reserve Bank of San Francisco. Available at http://www.frbsf.org/publications/economics/letter/2004/el2004-27.pdf.

Krugman, Paul. 2005. "That Hissing Sound." New York Times, August 8. Available at http://www.nytimes.com/2005/08/08/opinion/08krugman.html.

Laing, Jonathan R. 2005. "The Bubble's New Home." Barron's Online, June 20. Available at http://4sarasotahomes.com/images/6-20-05Barrons-Bubble.pdf.

Leamer, Edward E. 2002. "Bubble Trouble? Your Home Has a P/E Ratio Too." UCLA Anderson Forecast, June. Available at http://www.anderson.ucla.edu/faculty/edward. leamer/pdf_files/LeamerForecasts/20022006BubbleTrouble.pdf.

Lo, Andrew W., and A. Craig MacKinlay. 2001. A Non-Random Walk Down Wall Street. Princeton, N.J.: Princeton University Press.

Mankiw, N. Gregory, and David N. Weil. 1989. "The Baby Boom, the Baby Bust, and the Housing Market." Regional Science and Urban Economics 19 (2): 235-258.

Mayer, Christopher. 2003. "[Is There a Bubble in the Housing Market?]. Comments and Discussion." Brookings Papers on Economic Activity 2003 (2): 343-354.

McCarthy, Jonathan, and Richard W. Peach. 2004. "Are Home Prices the 'Next Bubble'?" Economic Policy Review. New York: Federal Reserve Bank of New York. Available at http://www.newyorkfed.org/research/epr/04v10n3/0412mcca.pdf.

Quigley, John. 2003. "[Is There a Bubble in the Housing Market?]. Comments and Discussion." Brookings Papers on Economic Activity 2003 (2): 354-358. 
Saiz, Albert. 2010. "The Geographic Determinants of Housing Supply." Working Paper. Wharton School of Business, University of Pennsylvania. Available at http: //real.wharton.upenn.edu/ saiz/GEOGRAPHIC $\backslash \%$ 20DETERMINANTS.pdf.

Shiller, Robert J. 2006. "Long-Term Perspectives on the Current Boom in Home Prices." The Economists' Voice 3 (4): 1-4. Available at http://www.bepress.com/ev/vol3/iss4/ $\operatorname{art} 4 /$.

Smith, Margaret Hwang, and Gary Smith. 2006. "Bubble, Bubble, Where's the Housing Bubble?" Brookings Papers on Economic Activity 2006 (1): 1-50.

Smith, Vernon L., Gerry L. Suchanek, and Arlington W. Williams. 1988. "Bubbles, Crashes, and Endogenous Expectations in Experimental Spot Asset Markets." Econometrica 56 (5): 1119-1151.

Zuckerman, Gregory. 2009. The Greatest Trade Ever: The Behind-the-Scenes Story of How John Paulson Defied Wall Street and Made Financial History. New York, N.Y.: Broadway Books. 
Figure 1. The Housing Price-Rent Ratio in the United States: 1983:Q1-2010:Q1

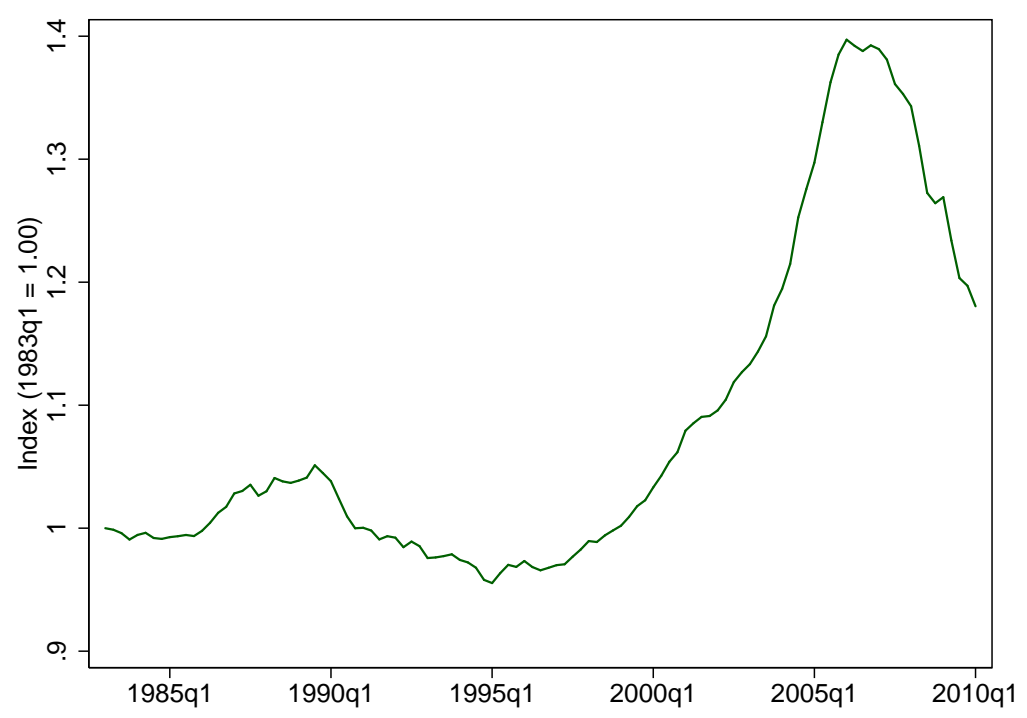

Sources: National house price series from the Office of Housing Enterprise Oversight (OFHEO). Owner's equivalent rent series from the Bureau of Labor Statistics (BLS). 
Figure 2. House Price Growth and Supply Elasticities in 92 Metropolitan Areas

Figure 3. House Price Growth and Supply Elasticities in Metropolitan Areas with Saiz Elasticities below 3

Panel A: 1995:Q4-2005:Q4

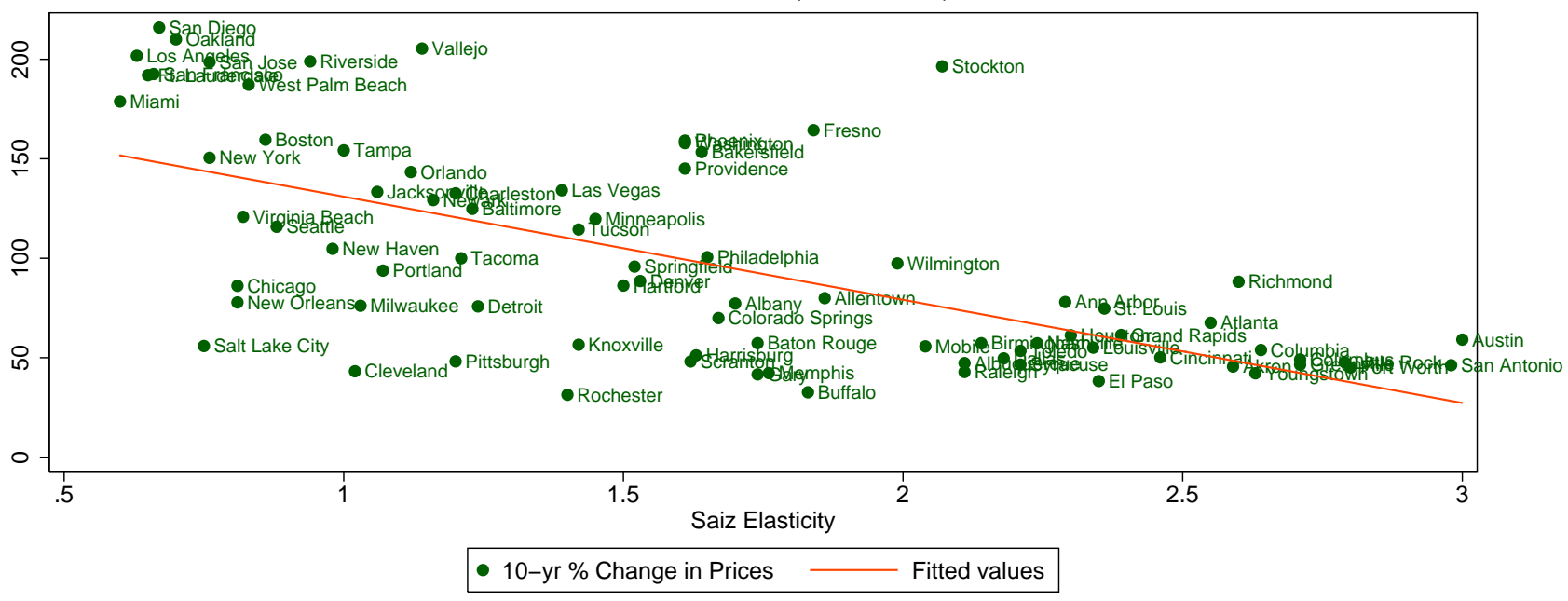

Panel B: 1999:Q4-2002:Q4

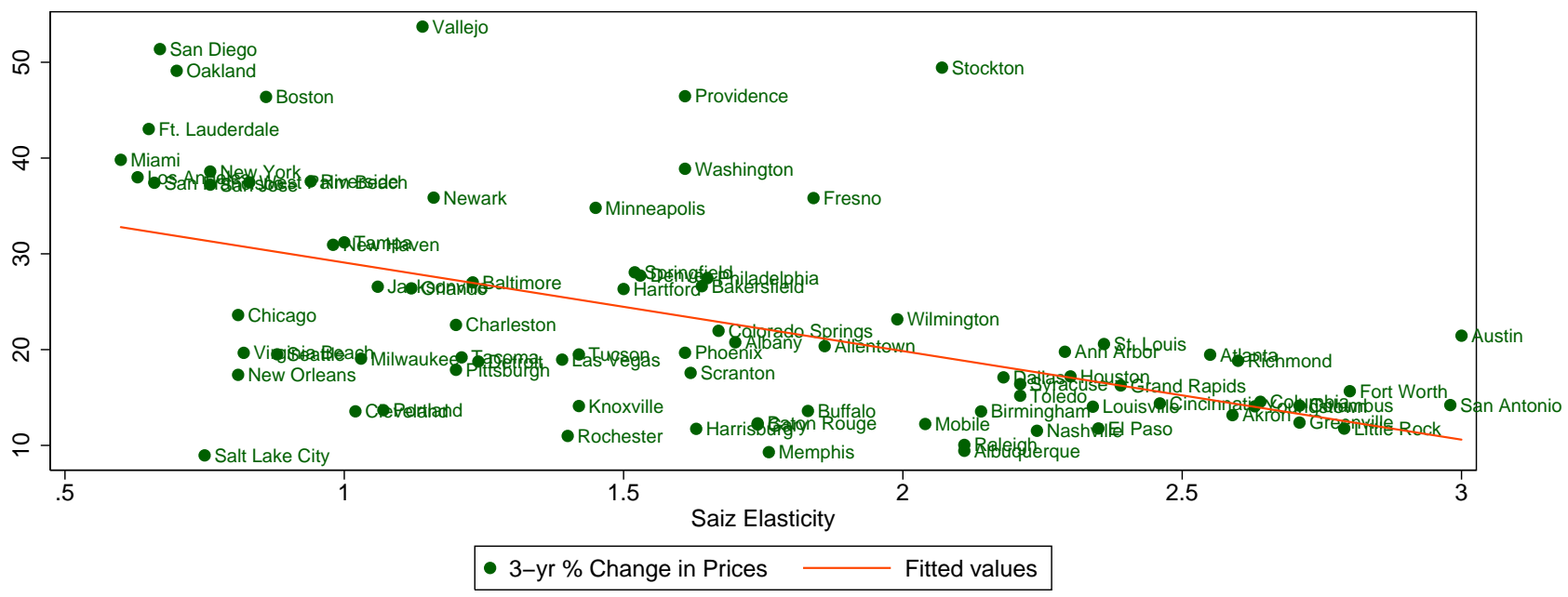

Panel C: 2002:Q4-2005:Q4

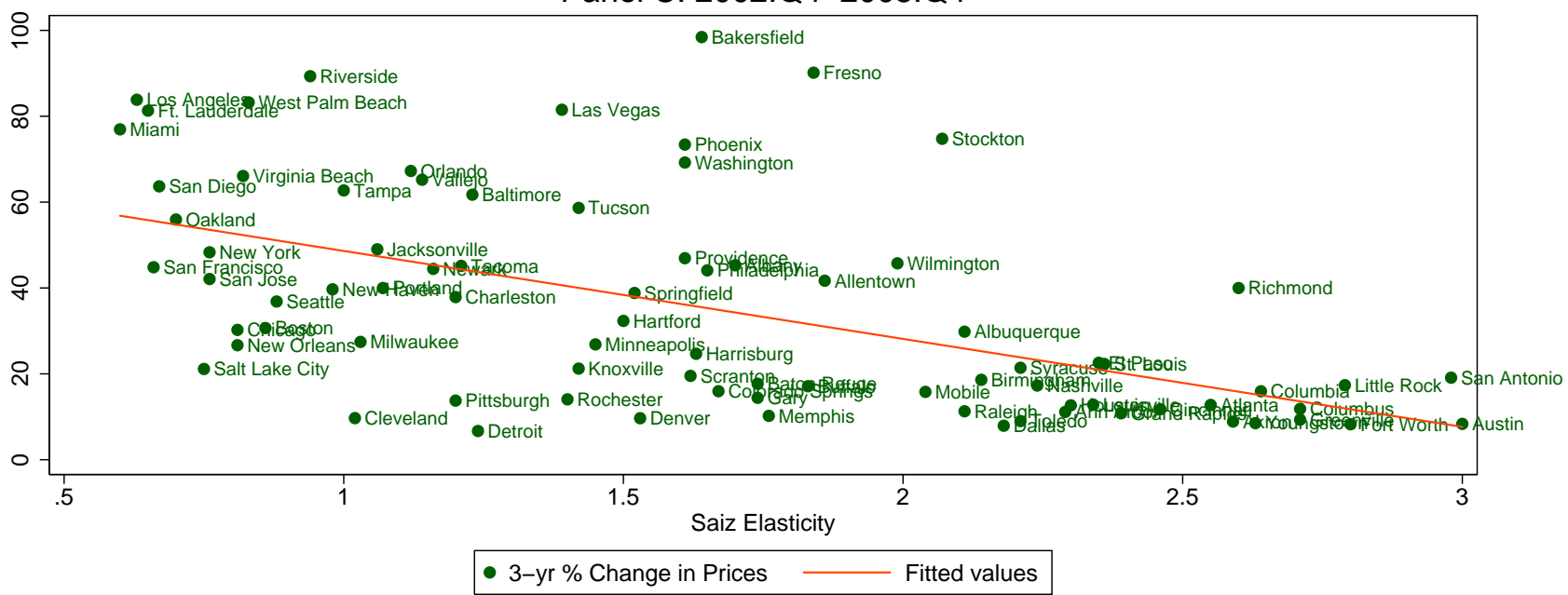

Sources: Supply elasticities are from Saiz (2010). House prices are from the Office of Federal Housing Enterprise Oversight (OFHEO). 
Figure 4. House Price Appreciation and New Construction on the State Level

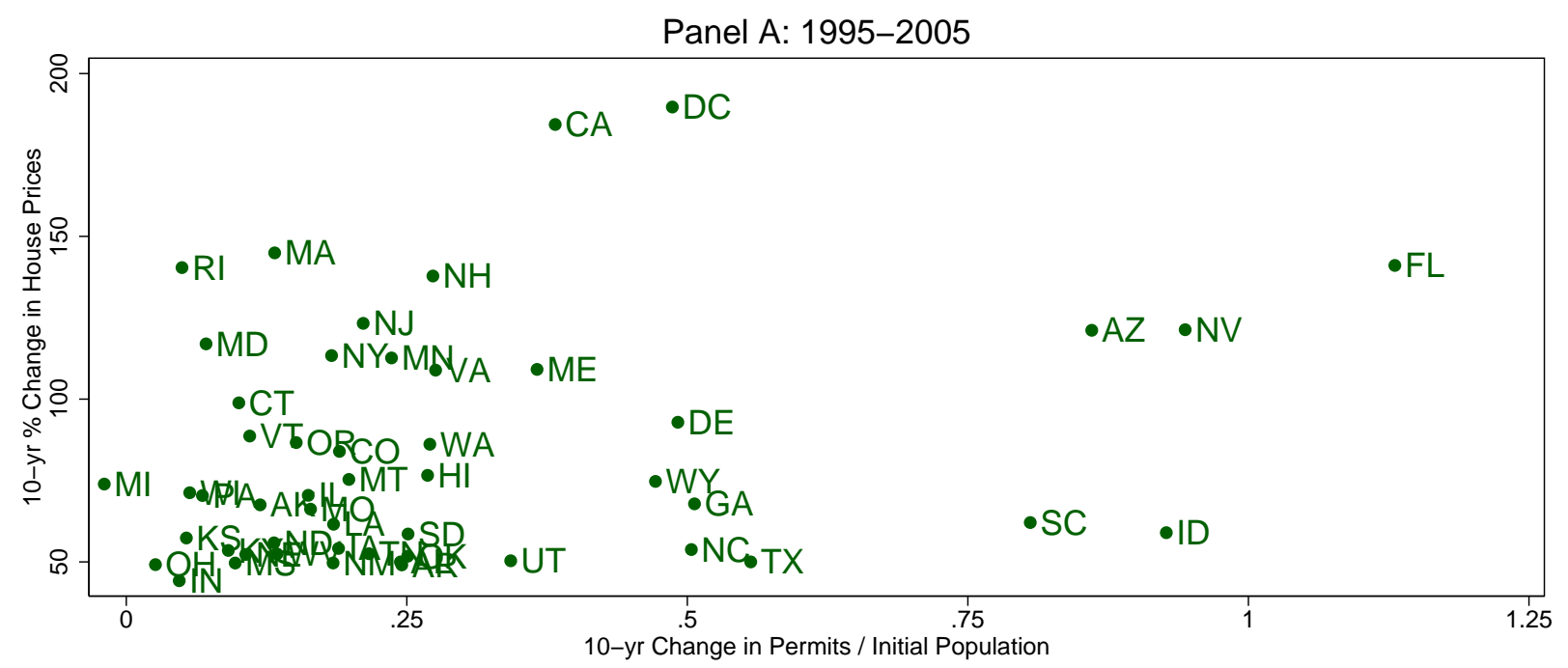

Panel B: 1999-2002

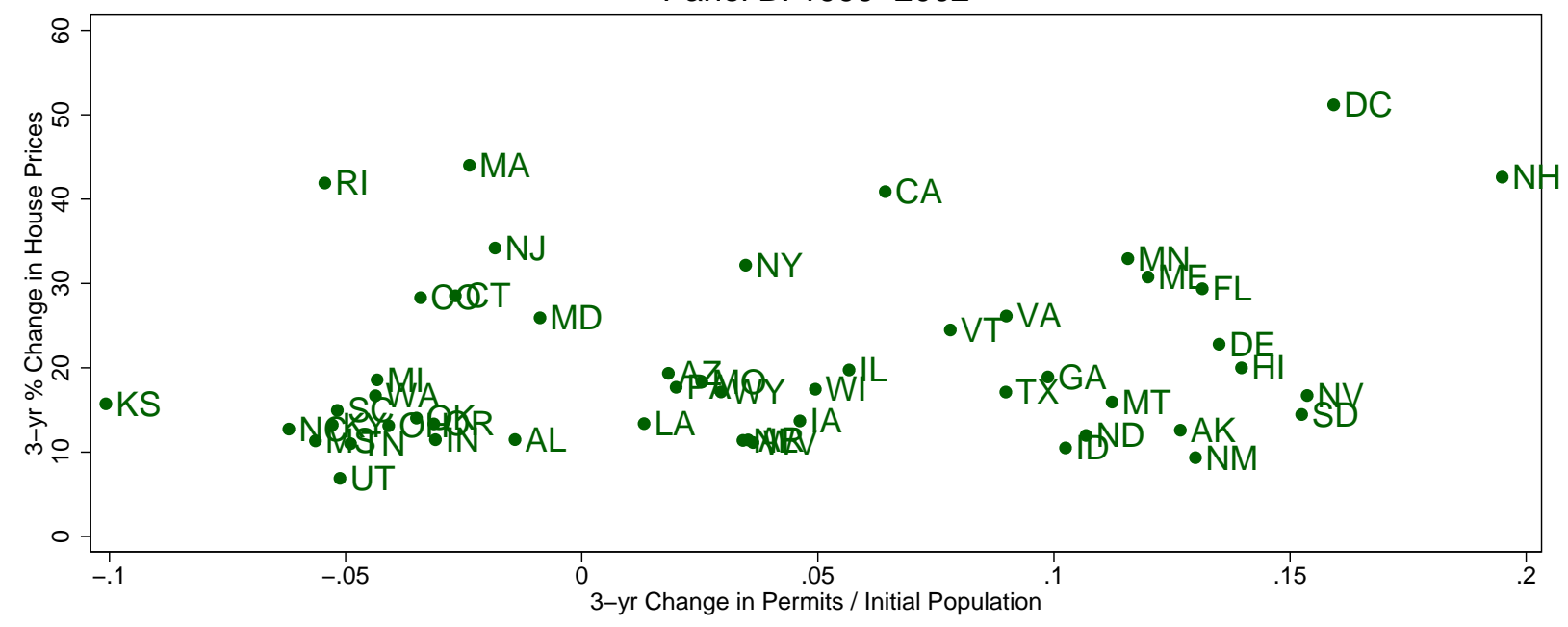

Panel C: 2002-2005

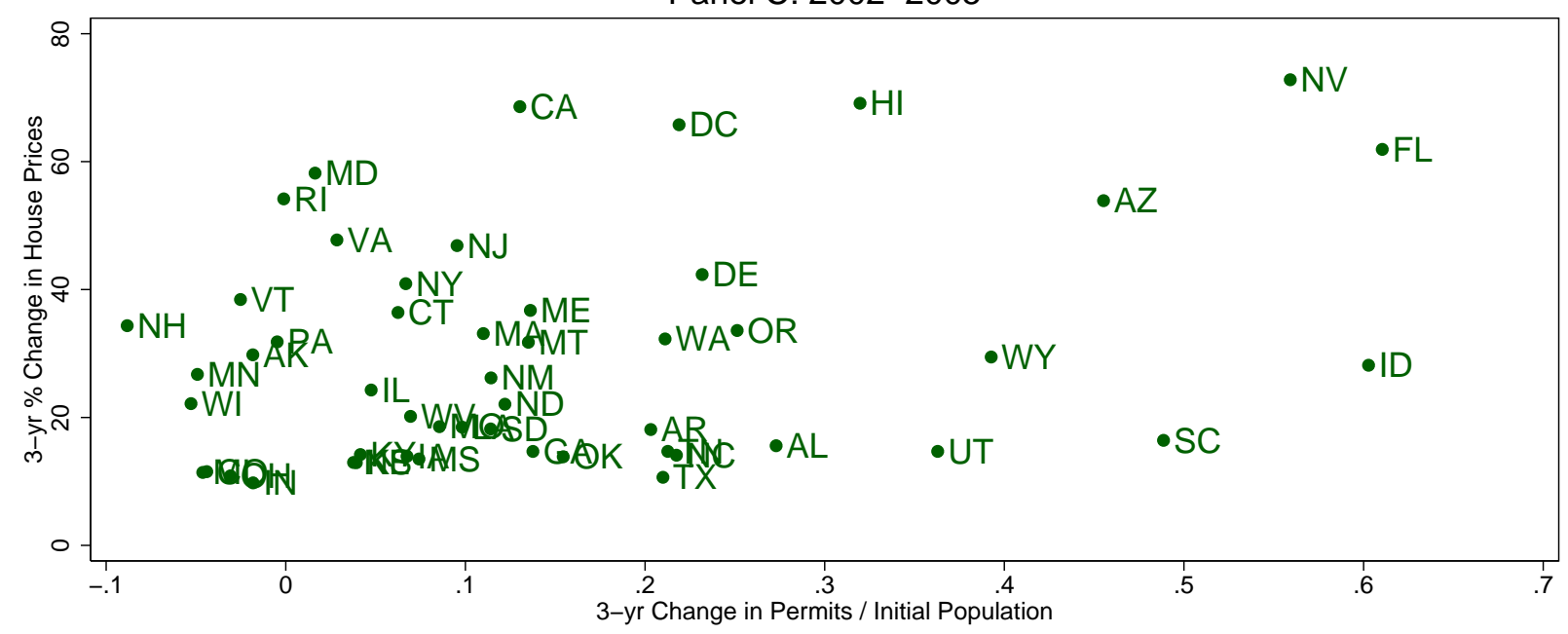

Sources: House prices are from OFHEO. State-level building permits and initial population levels are from the Bureau of the Census. 